\title{
Development of erectile dysfunction in men treated for major depressive disorder with selective serotonin reuptake inhibitors: a systematic review
}

\author{
Ahmed Mohammed Alhuwaydi
}

Department of Internal Medicine, College of Medicine, Jouf University, Sakaka, Saudi Arabia

Submitted: 31 January 2020

Accepted: 2 August 2020

Arch Med Sci

DOI: https://doi.org/10.5114/aoms.2020.98424

Copyright $\odot 2020$ Termedia \& Banach

\section{Abstract}

Introduction: Sexual dysfunction (SD) is known to be associated with selective serotonin reuptake inhibitors (SSRIS). To determine the effect of different SSRIs on SD development in males, particularly erectile dysfunction (ED), a systematic review was conducted according to PRISMA guidelines.

Material and methods: Literature, in English language, published between January 2009 and September 2019 was searched using two electronic databases, PubMed and EMBASE. Studies were screened according to the predefined inclusion-exclusion criteria. The bibliographies of the included articles were screened to identify any relevant articles.

Results: A total of ten articles were included (8/811 articles searched; two from bibliographies of eight included articles). Treatment-emergent SD, particularly ED was observed in male participants, although the ED incidence was low, less than $2 \%$. SSRIs - fluoxetine, escitalopram, and citalopram showed a higher risk of ED than other SSRIs.

Conclusions: The findings indicated a positive association between SSRIs and SD. However, evidence supporting a strong link between SSRIs and ED was insufficient.

Key words: antidepressants, male sexual dysfunction, adverse effect, penile erection, sexual behavior.

\section{Introduction}

Major depressive disorder (MDD) is a complex, multi-faceted, recurrent psychiatric disorder associated with reduced functional ability, poor quality of life (QoL), and high morbidity and mortality [1]. It is one of the predominant causes of disability globally [2]. The World Health Organization (WHO) lists depression as the fourth leading cause of disability worldwide and anticipated that it will be the second leading cause by 2020 [1, 3]. Accurate information about the global prevalence of MDD is essential to reduce this mental disability [4]. Bromet et al. conducted a study on 18 countries (ten high-income and eight low-income countries) and estimated the average lifetime and 12-month prevalence rates of MDD to be $14.6 \%$ and $5.5 \%$, respectively, in ten high-income countries, and $11.1 \%$ and $5.9 \%$, respectively, in eight low-income countries [1].

The management of MDD largely involves psychological or pharmacological therapy or a combination of both, which needs to be applied during the entire period of depression [5-7]. According to the practice

\author{
Corresponding author: \\ Ahmed Mohammed \\ Alhuwaydi \\ Department of Internal \\ Medicine \\ College of Medicine \\ Jouf University \\ Sakaka, Saudi Arabia \\ Phone: +96 6561449444 \\ E-mail: \\ amalhuwaydi@ju.edu.sa
}


guidelines of the American Psychiatric Association (APA), the treatment must be specific for the individual patient, depending on disease severity, comorbid psychiatric and physical conditions, and the level of functioning $[5,6,8,9]$. The standard treatment of care for MDD is antidepressant medications; among them, the recommended first-line treatment is selective serotonin reuptake inhibitors (SSRIs) [10]. These medications are widely used because of their superior tolerability, higher efficacy, better safety, and simpler titration as compared to the other antidepressants [7, 11-14].

The commonly used SSRIs are citalopram, fluoxetine, fluvoxamine, escitalopram, paroxetine, and sertraline. Usually, SSRIs, analogously to other antidepressants, require several weeks to even a few months to alleviate the symptoms of depression; hence, patients must adhere to the medication for a specific period [10]. However, SSRIs are known to produce treatment-emergent sexual dysfunction (TESD) as an adverse event (AE), which considerably affects a person's QoL, self-esteem, and relationships [15]. Subsequently, many patients show non-adherence or discontinue treatment [10]. Hence, the treatment outcome is adversely affected, which is an essential clinical concern in the management of MDD patients [16].

The human sexual response cycle (desire, arousal, and orgasm) is a complex biopsychological cycle [17]. Some studies have suggested that the physiology of sexual functioning and mood regulation revolves around the mechanism of action of three different neurotransmitters - serotonin, dopamine, and norepinephrine - with serotonin, also known as 5 -hydroxytryptophan $(5 \mathrm{HT})$, having a negative effect on sexual desire in contrast to dopamine $[18,19]$. An increased level of serotonin reduces sexual function by delaying vaso-congestion (reducing arousal mechanism in sexual organs) and lowering the sensation of the reproductive structure $[15,18]$. Moreover, the serotoninergic nerve terminal inhibits the activity of dopamine and norepinephrine pathway, thus reducing sexual desire and arousal [15]. SD associated with SSRI mainly results from an elevated level of serotonin (5HT2 and $5 \mathrm{HT} 3$ ), decreased dopamine, blockage of cholinergic and $\alpha 1$ receptors, increased prolactin, and reduced nitric oxide (NO) activity $[15,16,20]$.

SSRI registration studies, at the earlier stages, identified only $10 \%$ of patients reporting TESD after taking SSRI [21]. However, about $60-70 \%$ of patients were found to develop TESD when the doctors directly asked them about the specific AEs [21-23]. The sexual AEs and specific sexual experience may vary from patient to patient [13]. SD includes at least one of the following: decreased libido, erectile dysfunction (ED) or reduced arousal, vaginal dryness, premature ejaculation, delay in achieving orgasm or anorgasmia, and decreased pleasure during orgasm [21, 23].

ED is primarily caused by disruption of the complex interactions of vascular, neurologic, hormonal, and psychological factors required for normal erection and secondarily caused by certain medications, such as antidepressants and antihypertensives [23]. Penile erection is thought to be under the control of the adrenergic system since many adrenergic nerve fibers innervate the penile contractile and erectile tissue [24]. Additionally, $\mathrm{NO}$ is responsible for smooth muscle relaxation of the vasculature of the penis through cyclic guanosine monophosphate, leading to vasodilation and adequate blood supply to the penis allowing erection physiologically; therefore, reduced action of NO causes a problem with erection [15, 24]. Serotonin is also known to reduce the NO level [24]. Besides this indirect effect on penile erection through NO level, serotonin plays a direct role in ED development [24]. Supraspinal areas of the brain and preganglionic sacral neurons responsible for sexual excitement possess significant serotonergic activity indicating a direct role of serotonin in ED development [24].

SSRIs, although particularly selective for the serotonergic system, also affect other neurotransmitter systems [24]. Paroxetine, at a high dose, blocks the reuptake of norepinephrine and also possesses a clinically remarkable anticholinergic effect, while sertraline and fluoxetine inhibit both norepinephrine and dopamine uptake [24]. A prospective clinical study, including 344 participants, determined that paroxetine was responsible for causing the highest number of sexual AEs (64.71\%), followed by fluvoxamine $(58.94 \%)$, sertraline (56.4\%), and fluoxetine (54.38\%), and the most significant AE of paroxetine is ED, indicating variation in the effect of different SSRIs on the development of SD or even ED in males [25].

The present systematic review aimed to evaluate the available literature on high-evidenced clinical studies and randomized controlled trials (RCTs) to reach a better conclusion about the effect of different types of SSRI medications on the development of SD, particularly ED in male patients suffering from MDD.

\section{Material and methods}

The systematic review was conducted according to the Preferred Reporting Items for Systematic Reviews and Meta-Analyses (PRISMA) guidelines [26].

\section{Search strategy}

To carry out this review, published literature in the English language was searched using two 
electronic databases, PubMed and EMBASE. The keywords "selective serotonin reuptake inhibitors", and "sexual behavior" were combined and Boolean operators "AND" and "OR" were used to obtain a broad search strategy. The search strategy used for each database is presented in Table I. Studies were screened according to the predefined inclusion and exclusion criteria. Additionally, the reference lists of the articles included after secondary search were screened to identify any additional articles relevant to the topic.

\section{Inclusion and exclusion criteria}

Studies were deemed eligible for inclusion if they met the following criteria: (1) were clinical studies or clinical trials (Phases 1 , or 2, or 3. or 4), or randomized controlled trials, conducted in last ten years on MDD patients receiving SSRI medications, (2) had reported any health outcome associated with SD, particularly ED, as an AE with SSRI medications used to treat MDD, (3) had an emphasis on SD and/or ED in adult males with MDD, and (4) were published in English-language refereed journals. Although the review focused on the male population, studies conducted both on adult male and female MDD patients taking SSRI medications were included in this review due to the unavailability of studies conducted solely on male patients suffering from MDD and treated with SSRI.

Studies conducted on subjects of age less than 18 years, or healthy individuals, or individuals suffering from other depressive episodes and anxiety disorders instead of MDD, or individuals not taking SSRI antidepressants, or individuals suffering from ED before taking SSRIs, or studies not fulfilling the research objective, were excluded from this review.

\section{Selection of studies}

The titles and abstracts of retrieved records were combined and transferred into the digital reference manager (EndNote) and the duplicate articles were removed. Two levels of screening were conducted. The first selection step or the primary search was based on the title and the abstract of the retrieved articles. In the second step or secondary search, the articles meeting the inclusion criteria based on their title and abstract were subjected to complete reading. After reading the full articles, the relevant articles to be included in the review were selected.

\section{Quality assessment and data extraction}

Studies meeting the eligibility criteria were assessed for the methodological quality. The methodological quality of the included studies was assessed by the Jaded score. This methodological assessment tool estimates the descriptions of randomization, blinding, and withdrawals in the RCTs. The description of the Jaded quality score is as follows: i) whether randomized or not (yes = 1 point, no $=0$ ), ii) whether appropriate description of randomization is provided or not (yes = 1 point, no $=0$ ), iii) double blind (yes $=1$ point, no $=0$ ), iv) whether appropriate description of double blinding is provided (yes $=1$ point, no $=0$ ), v) whether description of withdrawals and dropouts is provided or not (yes $=1$ point, no $=0$ ). Jaded quality score is a 0 - to 5 -point scale with a score of 2 or less indicating a low-quality score and a score of at least 3 or more indicating high quality [27]. The included studies were then subjected to data extraction. The extracted data were aligned to the review question. A data extraction

Table I. Description of database search strategy for the review

\begin{tabular}{|c|c|c|c|}
\hline $\begin{array}{l}\text { Database } \\
\text { searched }\end{array}$ & Search dates & Keywords searched & Search Filters \\
\hline PubMed & $\begin{array}{l}\text { Jan } 2009 \text { to } \\
\text { Sept } 2019\end{array}$ & 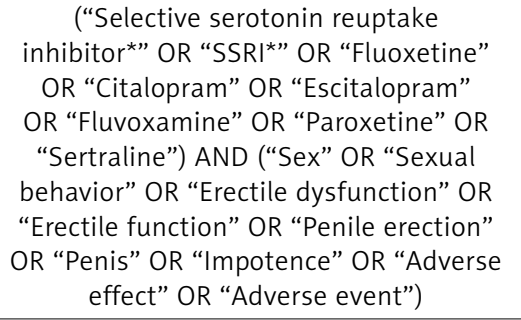 & $\begin{array}{c}\text { Clinical Trial, Clinical Trial, Phase I, Clinical } \\
\text { Trial, Phase II, Clinical Trial, Phase III, } \\
\text { Clinical Trial, Phase IV, Observational } \\
\text { Study, Randomized Controlled Trial, } \\
\text { Comparative Study Multicenter Study, } \\
\text { Published in the last } 10 \text { years, Humans, } \\
\text { English }\end{array}$ \\
\hline EMBASE & $\begin{array}{l}\text { Jan } 2009 \text { to } \\
\text { Sept } 2019\end{array}$ & 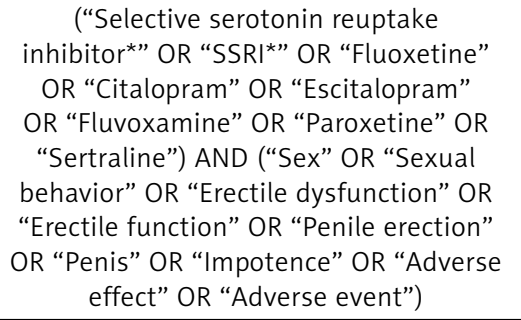 & $\begin{array}{c}\text { Publication years from } 2009 \text { to } 2019 \text {, } \\
\text { humans, clinical studies, only in English, } \\
\text { Controlled clinical trials, Randomized } \\
\text { trials, Articles }\end{array}$ \\
\hline
\end{tabular}


table was prepared, which summarized all the data points used for the analysis of the included studies. The extracted data included the following information: i) study characteristics (such as study design, duration, country of study, inclusion and exclusion criteria, and study objective), ii) study participants, iii) sample size (including randomized samples, actual participants, withdrawals from the study), iv) intervention (drugs, dose, duration, and study groups based on different drugs received), v) outcome measures, and vi) adverse events, particularly SD and/or ED associated with the SSRIs.

The extracted data were analyzed descriptively. The extracted data points from the included studies were presented as a narrative synthesis in this systematic review.

\section{Results}

\section{Literature search results}

The initial electronic database search retrieved a total of 811 articles (213 from PubMed and 598 from EMBASE) based on predefined search criteria. Among them, 102 were duplicate articles, hence excluded, leaving 709 effective articles for screen- ing. After primary search, 24 articles were found to be potentially relevant for the review according to the information obtained in their abstracts. The full texts of these articles were then screened and 17 were identified for probable inclusion in the review and seven were rejected for different reasons (different aim and outcomes, inappropriate publication type). The full text of these 17 articles was read again carefully to assess whether they fulfill the aims of this review. After completion of reading, nine additional studies were excluded in this step due to different aims or inappropriate publication types. Thus, eight articles were eligible for inclusion in the study. Since the number of articles included was lower, the reference lists of these eight articles were scrutinized for additional articles relevant to the topic. The bibliography search resulted in the identification of two more studies potentially meeting the inclusion criteria of this review. Therefore, a total of ten studies were eligible for the final analysis (Figure 1). All these studies included both depressed male and female patients; however, this review only highlighted the male patients developing SD, particularly ED under the effect of different SSRIs.

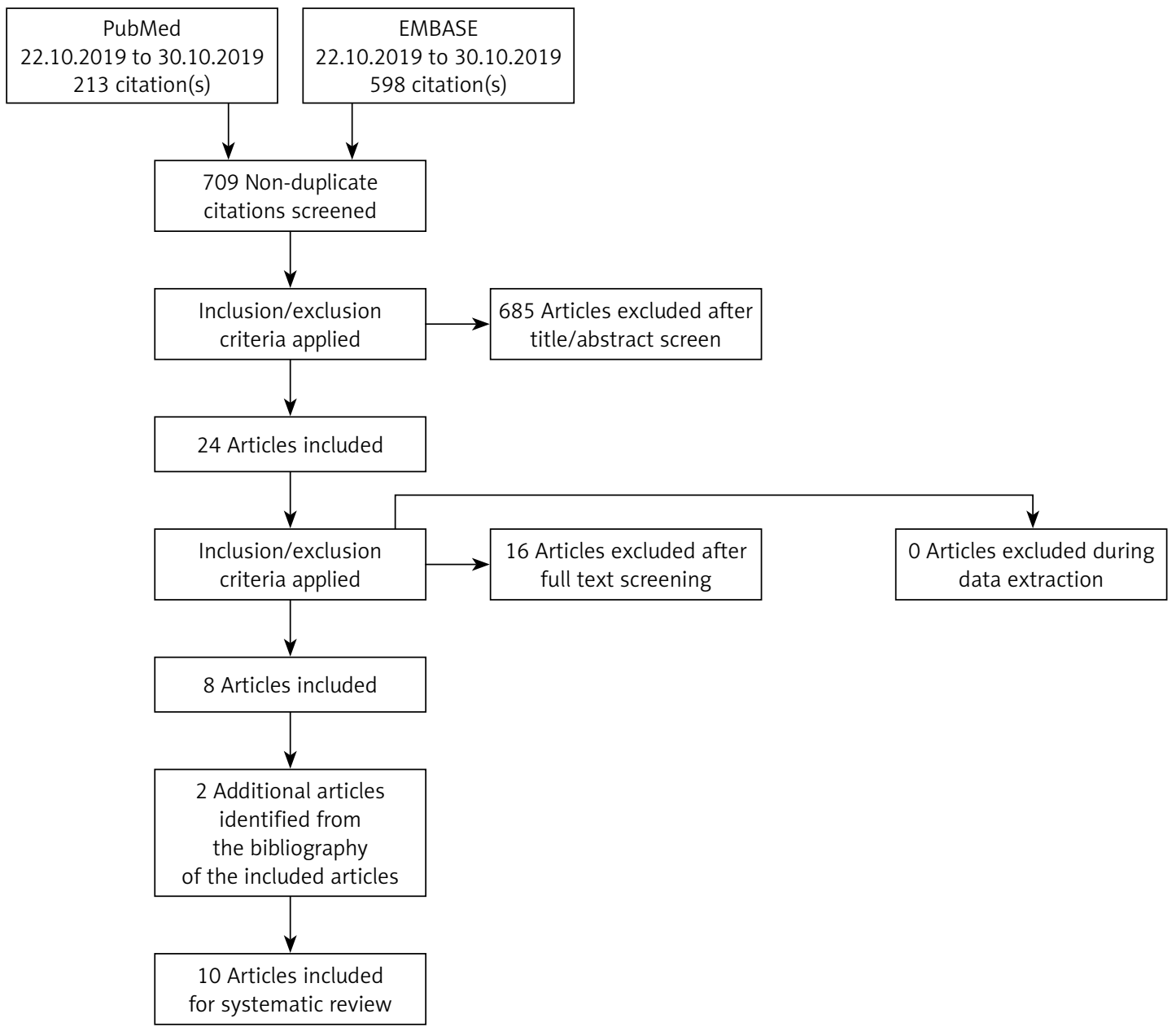

Figure 1. Flow diagram: summary of search process and selection 


\section{Overview of study characteristics}

The name of the authors who conducted the study, the study design, duration, objective, study location, study population, outcome measures, drug intervention, and AEs of all drugs related to each study are summarized in Table II. All ten studies included for analysis were published in English between January 2009 and September 2019. A large variation was observed among the duration of the included studies ranging between eight and 52 weeks; one study had a duration of 14 weeks [7], the majority of the studies had a duration of 8 to 12 weeks [22, 28-33], one study had a duration of 52-weeks [34], and the duration was not mentioned for one study [35].

\section{Study design}

Nine out of ten studies were randomized trials [7, 22, 28-34], and one was a cross-sectional study [35]. Among nine randomized trials, seven used a double-blind procedure [22, 29-34], one used a single-blind procedure [7], and one did not blind the patients, physicians, and researchers to treatment allocation [28].

\section{Study quality assessment}

Out of ten studies, five studies had a score of $3[7,22,28,31,34]$, three studies had a score of $5[29,30,33]$, and one study had a score of 4 [32]; therefore a total of nine studies had a quality score of 3 or more and were of high quality. Only one study was a cross-sectional survey, so the Jaded score was zero and was of low quality [35]. The quality scores of the included studies are presented in Table III.

\section{Study population}

All ten studies included adult male and female participants of age 18 years or more, suffering from MDD and treated with different SSRI medications. There was heterogeneity in the sample size across the studies ranging from 195 [7] to 1162; except two studies $[7,33]$ all eight studies had more than 600 participants $[22,28-32,34$, 35]. The patients with MDD were included in the study if they met the criteria of Diagnostic and Statistical Manual of Mental Health $4^{\text {th }}$ ed. text version (DSM-IV-TR) and had an ongoing depressive episode lasting more than eight weeks [7, 22, 29-34], or met the International Classification of Disease-10 $0^{\text {th }}$ Revision (ICD-10) criteria for depression (category F32) [28]. All the studies excluded individuals with unstable psychotic symptoms, suicidal tendencies, clinically significant medical history, substance abuse, or a history of SD before taking SSRI medication.

\section{Study objectives}

Most studies (7 out of 10) were designed to assess the sexual AEs of different SSRI medications on adult MDD patients [7, 22, 28, 31-33, 35]. Two studies aimed to detect the safety, efficacy, and tolerability of vilazodone in the treatment of MDD $[29,30]$, and one study was designed to evaluate the long-term safety and tolerability of higher doses of vortioxetine.

\section{Drug intervention}

Different types of SSRI medications were used in these studies including fluoxetine, vortioxetine, vilazodone, sertraline, citalopram, paroxetine, and escitalopram. As a control or comparator, a selective serotonin and norepinephrine reuptake inhibitor (SNRI), such as venlafaxine and duloxetine, or a noradrenaline reuptake inhibitor, such as reboxetine, was used in some studies [28, 32, 35]. The doses of SSRI medications varied in the studies. Vilazodone was used at two doses, $20 \mathrm{mg} /$ day and $40 \mathrm{mg} /$ day $[22,29,30]$; vortioxetine was used at a dose of $10 \mathrm{mg}$ to $20 \mathrm{mg} /$ day [32-34]; fluoxetine was used at a dose of 20-60 mg/day; and escitalopram was used at a dose of $20 \mathrm{mg} / \mathrm{day}$ [33]. For citalopram, the initial dose was $20 \mathrm{mg} /$ day, which was increased to $30 \mathrm{mg} /$ day to $40 \mathrm{mg} /$ day [28].

\section{Outcome measures}

All these studies considered two types of outcomes of the SSRIs: i) related to sexual function, ii) related to depressive symptoms. For this systematic review, the outcome measure primarily involved the assessment of the sexual AEs of the SSRI medications, particularly ED in male participants. Different studies used diverse ways to collect information on sexual functioning. A self-administered questionnaire (a modified version of the Toronto Side Effects Scale) was used to measure 14 physical symptoms at baseline, 6 weeks, and 12 weeks to identify the occurrence of AEs in one study [28]. The Sexual Function Questionnaire (SFQ), a self-report questionnaire evaluating three domains of sexual function (desire, arousal, and orgasm), was used to assess the sexual function of the patients before and after treatment in one study and reported about internal consistency (Cronbach's $\alpha$ coefficient was 0.70 ) and test-retest reliability [7]. The Change in Sexual Functioning Questionnaire (CSFQ-14) tool was used in four studies [22, 29, 33, 34]. CSFQ-14 is a 14-item self-report scale consisting of several domains, which assesses different phases of the sexual cycle. CSFQ is mostly used to measure changes in sexual functioning associated with the effects of antidepressant treatment [22]. A decrease in 
Table II. Characteristics of the 10 included studies

\begin{tabular}{|c|c|c|c|c|c|}
\hline $\begin{array}{l}\text { Authors } \\
\text { (year of study) }\end{array}$ & $\begin{array}{l}\text { Study design; } \\
\text { study duration }\end{array}$ & $\begin{array}{l}\text { Sample } \\
\text { size }\end{array}$ & $\begin{array}{c}\text { Sample } \\
\text { characteristics }\end{array}$ & Drug intervention & $\begin{array}{l}\text { Adverse sexual } \\
\text { effects due to SSRI } \\
\text { treatment }\end{array}$ \\
\hline $\begin{array}{l}\text { Crawford et al. } \\
\text { (2014) [28] }\end{array}$ & $\begin{array}{c}\text { Multicenter, } \\
\text { randomized } \\
\text { controlled trial; } \\
12 \text { weeks }\end{array}$ & 601 & $\begin{array}{l}\text { Adult male }(n=193) \\
\text { and female patients } \\
(n=408) \text { of age } \\
\text { 18-74 years with } \\
\text { depression fulfilling } \\
\text { the International } \\
\text { Classification } \\
\text { of Disease-10th } \\
\text { Revision (ICD-10) } \\
\text { criteria for } \\
\text { depression } \\
\text { (category F32) }\end{array}$ & $\begin{array}{c}\text { Citalopram } \\
(20 \mathrm{mg} / \text { day initially } \\
\text { and then raised to } \\
30 \mathrm{mg}, 40 \mathrm{mg}) \\
(n=298), \text { reboxetine } \\
\text { at initial dose of } \\
10 \mathrm{mg} / \text { day, then } \\
\text { raised to } 12 \mathrm{mg} \text { and } \\
16 \mathrm{mg} / \text { day } \\
(n=303)\end{array}$ & $\begin{array}{l}\text { Erectile dysfunction } \\
\text { (ED) and difficulty in } \\
\text { ejaculation in males }\end{array}$ \\
\hline $\begin{array}{l}\text { Khazaie et al. } \\
\text { (2015) [7] }\end{array}$ & $\begin{array}{c}\text { Single-blind, } \\
\text { randomized } \\
\text { controlled trial; } \\
14 \text { weeks }\end{array}$ & 195 & $\begin{array}{l}\text { Adult male }(n=102) \\
\text { and female }(n=93) \\
\text { patients of age } \\
26-50 \text { years meeting } \\
\text { the Diagnostic and } \\
\text { Statistical Manual } \\
\text { of Mental Health } \\
4^{\text {th }} \text { ed. text version } \\
\text { (DSM-IV-TR) criteria } \\
\text { for major depressive } \\
\text { disorder (MDD) }\end{array}$ & $\begin{array}{l}\text { Fluoxetine }(n=67) \\
\text { (initial dose } \\
20 \mathrm{mg} / \text { day adjusted } \\
\text { to } 40 \mathrm{mg} / \text { day) and } \\
\text { sertraline }(n=64), \\
\text { initial dose } \\
50 \mathrm{mg} / \text { day and } \\
\text { then to } 200 \mathrm{mg} / \text { day, } \\
\text { trazodone }(n=64)\end{array}$ & $\begin{array}{l}\text { In fluoxetine group, } \\
\text { less vigorous } \\
\text { erections in } \\
18 \text { males, fewer } \\
\text { sustained erections } \\
\text { in } 16 \text { males, fewer } \\
\text { spontaneous } \\
\text { erections in } \\
16 \text { males. } \\
\text { In sertraline group, } \\
\text { less vigorous } \\
\text { erections in } \\
14 \text { males, fewer } \\
\text { sustained erections } \\
\text { in } 13 \text { males, and } \\
\text { fewer spontaneous } \\
\text { erections in } 13 \text { males }\end{array}$ \\
\hline $\begin{array}{l}\text { Jacobsen et al. } \\
\text { (2015) [33] }\end{array}$ & $\begin{array}{l}\text { Randomized, } \\
\text { multicenter, } \\
\text { double-blind } \\
\text { trial; } 12 \text { weeks }\end{array}$ & 447 & $\begin{array}{l}\text { Male }(n=184) \text { and } \\
\text { female }(n=263) \\
\text { of age } 18-55 \text { years } \\
\text { with MDD and were } \\
\text { on a stable selective } \\
\text { serotonin reuptake } \\
\text { inhibitor (SSRI) } \\
\text { treatment regimen. } \\
\text { Eligible participants } \\
\text { were required to be } \\
\text { sexually active at } \\
\text { least every } 2 \text { weeks } \\
\text { before onset of MDD } \\
\text { or SSRI use }\end{array}$ & $\begin{array}{c}\text { Vortioxetine } \\
(20 \mathrm{mg} / \text { day }) \\
(n=222) \text { and } \\
\text { escitalopram } \\
(20 \mathrm{mg} / \text { day }) \\
(n=225) ; \\
97 \text { males received } \\
\text { vortioxetine and } \\
87 \text { males received } \\
\text { escitalopram }\end{array}$ & $\begin{array}{l}\text { Nine (9) patients in } \\
\text { escitalopram group } \\
\text { showed sexual side } \\
\text { effects including } \\
\text { decreased libido } \\
(n=5) \text {, anorgasmia, } \\
\text { delayed ejaculation, } \\
\text { disturbance in sexual } \\
\text { arousal, and erectile } \\
\text { dysfunction (ED) } \\
\text { (all } n=1 \text { ). No patient } \\
\text { in vortioxetine } \\
\text { group spontaneously } \\
\text { reported any adverse } \\
\text { event related to } \\
\text { sexual dysfunction } \\
\text { (SD) }\end{array}$ \\
\hline $\begin{array}{l}\text { Williams et al. } \\
\text { (2010) [35] }\end{array}$ & $\begin{array}{l}\text { Cross-sectional } \\
\text { survey study; } \\
\text { duration } \\
\text { unknown }\end{array}$ & 704 & $\begin{array}{c}\text { Adult male }(n=207) \\
\text { and female }(n=497) \\
\text { of age at least } \\
18 \text { years taking SSRI } \\
\text { medications for no } \\
\text { less than } 3 \text { months } \\
\text { and no more than } \\
6 \text { months of the } \\
\text { study period }\end{array}$ & $\begin{array}{c}\text { Citalopram }(n=105) \text {, } \\
\text { sertraline }(n=56), \\
\text { fluoxetine }(n=166), \\
\text { paroxetine }(n=169), \\
\text { and venlafaxine } \\
(n=142) \text {. In German } \\
\text { sample the most } \\
\text { used antidepressant } \\
\text { was venlafaxine } \\
(34.0 \%) n=87 \text {, in } \\
\text { Spain, fluoxetine } \\
(44.0 \%) n=113 \text {, and } \\
\text { in the Netherlands, } \\
\text { paroxetine }(30.9 \%) \\
n=59\end{array}$ & $\begin{array}{c}\text { Changes in sexual } \\
\text { functioning included } \\
\text { sex drive, arousal, } \\
\text { erection, and } \\
\text { orgasm. } \\
\text { In Germany, } 22.6 \% \\
\text { of males reported } \\
\text { about a little worse } \\
\text { and much worse ED, } \\
\text { in Spain } 40.4 \% \text { and } \\
9.6 \% \text { reported a little } \\
\text { worse and much } \\
\text { worse ED, and in the } \\
\text { Netherlands } 38.2 \% \\
\text { and } 16.4 \% \text { reported } \\
\text { the same }\end{array}$ \\
\hline
\end{tabular}


Table II. Cont.

\begin{tabular}{|c|c|c|c|c|c|}
\hline $\begin{array}{l}\text { Authors } \\
\text { (year of study) }\end{array}$ & $\begin{array}{l}\text { Study design; } \\
\text { study duration }\end{array}$ & $\begin{array}{l}\text { Sample } \\
\text { size }\end{array}$ & $\begin{array}{c}\text { Sample } \\
\text { characteristics }\end{array}$ & Drug intervention & $\begin{array}{l}\text { Adverse sexual } \\
\text { effects due to SSRI } \\
\text { treatment }\end{array}$ \\
\hline $\begin{array}{l}\text { Clayton et al. } \\
\text { (2015) [22] }\end{array}$ & $\begin{array}{l}\text { Post-hoc } \\
\text { analysis of } \\
\text { a primary } \\
\text { double-blind, } \\
\text { randomized, } \\
\text { phase IV- } \\
\text { controlled trial } \\
\text { comparing } \\
\text { vilazodone } \\
\text { with placebo } \\
\text { and citalopram } \\
\text { as an active } \\
\text { control; } \\
10 \text { weeks }\end{array}$ & 1138 & $\begin{array}{l}\text { Adult male and } \\
\text { female outpatients } \\
\text { of age } 18-70 \text { years } \\
\text { meeting DSM-IV-TR } \\
\text { criteria for MDD with } \\
\text { an ongoing major } \\
\text { depressive episode } \\
\text { lasting for at least } \\
8 \text { weeks and up to } \\
12 \text { months }\end{array}$ & $\begin{array}{c}\text { Vilazodone } \\
20 \text { mg/day }(n=288), \\
\text { vilazodone } \\
40 \mathrm{mg} / \text { day, } \\
\text { citalopram } \\
(40 \mathrm{mg} / \text { day }) \\
(n=287), \\
\text { citalopram } \\
(40 \mathrm{mg} / \text { day }) \\
(n=282), \text { and } \\
\text { placebo }(n=281)\end{array}$ & $\begin{array}{l}\text { Citalopram group } \\
\text { showed highest } \\
\text { treatment- } \\
\text { emergent SD } \\
\text { (TESD), particularly } \\
\text { anorgasmia and } \\
\text { loss of libido. ED in } \\
\text { males occurred in } \\
\text { similar frequencies } \\
\text { in the citalopram, } \\
\text { vilazodone, and } \\
\text { placebo groups } \\
\text { ( } n=3 \text { ). Decreased } \\
\text { libido among men: } \\
2 \text { in placebo, } 3 \text { in } \\
\text { vilazodone (20 mg/ } \\
\text { day), } 4 \text { in vilazodone } \\
\text { (40 mg/day), and } \\
2 \text { in citalopram group }\end{array}$ \\
\hline $\begin{array}{l}\text { Gelenberg et } \\
\text { al. (2013) [31] }\end{array}$ & $\begin{array}{l}\text { Multicenter, } \\
\text { randomized, } \\
\text { double-blind, } \\
\text { multiphase } \\
\text { trial; } 10 \text { weeks }\end{array}$ & 1096 & $\begin{array}{l}\text { Adult male }(n=381) \\
\text { and female }(n=666) \\
\text { outpatients of age } \\
18 \text { years or more } \\
\text { with recurrent MDD, } \\
\text { meeting DSM-IV } \\
\text { criteria for MDD }\end{array}$ & $\begin{array}{l}105 \text { males received } \\
\text { fluoxetine } \\
20-60 \mathrm{mg} / \text { day and } \\
276 \text { males received } \\
\text { and venlafaxine ER } \\
75-300 \mathrm{mg} / \text { day }\end{array}$ & $\begin{array}{c}\text { Low rates of } \\
\text { new-onset SD, } \\
\text { including abnormal } \\
\text { ejaculation, } \\
\text { anorgasmia, } \\
\text { impotence, and } \\
\text { reduced libido. ED in } \\
3 \text { males in fluoxetine } \\
\text { group and } 34 \text { males } \\
\text { in venlafaxine group }\end{array}$ \\
\hline $\begin{array}{l}\text { Mathews et al. } \\
\text { (2014) [29] }\end{array}$ & $\begin{array}{l}\text { Multicenter, } \\
\text { randomized, } \\
\text { double-blind, } \\
\text { placebo- } \\
\text { controlled, } \\
\text { parallel-group, } \\
\text { fixed-dose } \\
\text { study; } \\
10 \text { weeks }\end{array}$ & 1162 & $\begin{array}{l}\text { Adult male and } \\
\text { female patients } \\
\text { meeting DSM-IV- } \\
\text { TR criteria with } \\
\text { an ongoing major } \\
\text { depressive episode } \\
\text { lasting for at least } \\
8 \text { weeks and up to } \\
12 \text { months }\end{array}$ & $\begin{array}{c}\text { Vilazodone } \\
20 \text { mg/day } \\
(n=288), \\
\text { vilazodone } \\
40 \mathrm{mg} / \text { day }(n=287), \\
\text { citalopram } \\
20 \mathrm{mg} / \text { day }(n=257), \\
\text { and placebo } \\
(n=281)\end{array}$ & $\begin{array}{c}\text { Erectile dysfunction: } \\
n=3 \text { (placebo), } \\
n=3 \text { (vilazodone } \\
40 \text { mg/day), } \\
n=3 \text { (citalopram); } \\
\text { premature } \\
\text { ejaculation }(n=1) \\
\text { and ejaculation } \\
\text { failure }(n=1) \text { both } \\
\text { in citalopram group; } \\
\text { ejaculation delay } \\
(n=1) \text { in vilazodone } \\
(20 \text { mg/day) and } \\
n=2 \text { in each of } \\
\text { vilazodone } \\
(40 \text { mg/day) and } \\
\text { citalopram groups }\end{array}$ \\
\hline $\begin{array}{l}\text { Boulenger et } \\
\text { al. (2014) [32] }\end{array}$ & $\begin{array}{l}\text { Double-blind, } \\
\text { randomized, } \\
\text { fixed-dose, } \\
\text { placebo- } \\
\text { controlled, } \\
\text { active- } \\
\text { referenced } \\
\text { study; } 8 \text { weeks }\end{array}$ & 607 & $\begin{array}{l}\text { Adult male }(n=207) \\
\text { and female }(n=400) \\
\text { patients of age at } \\
\text { least } 18 \text { and up to } \\
75 \text { years meeting } \\
\text { DSM-IV-TR criteria } \\
\text { with an ongoing } \\
\text { major depressive } \\
\text { episode lasting for at } \\
\text { least } 8 \text { weeks and up } \\
\text { to } 12 \text { months }\end{array}$ & $\begin{array}{c}\text { Vortioxetine } \\
15 \mathrm{mg} / \text { day }(n=152), \\
\text { vortioxetine } \\
20 \mathrm{mg} / \text { day }(n=151), \\
\text { duloxetine } \\
60 \mathrm{mg} / \text { day }(n=147), \\
\text { and placebo } \\
(n=158)\end{array}$ & $\begin{array}{l}\text { The incidence of } \\
\text { AEs related to SD } \\
\text { (abnormal orgasm, } \\
\text { anorgasmia, } \\
\text { ejaculation delayed, } \\
\text { erectile dysfunction, } \\
\text { reduced libido, } \\
\text { lowered sensation, } \\
\text { sexual dysfunction) } \\
\text { was } 2.5 \% \text { in placebo, } \\
2.0 \% \text { in vortioxetine } \\
\text { (15 mg), } 4.0 \% \text { in } \\
\text { vortioxetine } \\
\text { (20 mg), and } 3.5 \% \text { in } \\
\text { duloxetine groups }\end{array}$ \\
\hline
\end{tabular}


Table II. Cont.

\begin{tabular}{|c|c|c|c|c|c|}
\hline $\begin{array}{l}\text { Authors } \\
\text { (year of study) }\end{array}$ & $\begin{array}{l}\text { Study design; } \\
\text { study duration }\end{array}$ & $\begin{array}{l}\text { Sample } \\
\text { size }\end{array}$ & $\begin{array}{c}\text { Sample } \\
\text { characteristics }\end{array}$ & Drug intervention & $\begin{array}{c}\text { Adverse sexual } \\
\text { effects due to SSRI } \\
\text { treatment }\end{array}$ \\
\hline $\begin{array}{l}\text { Croft et al. } \\
\text { (2014) [30] }\end{array}$ & $\begin{array}{l}\text { Multicenter, } \\
\text { randomized, } \\
\text { double-blind, } \\
\text { placebo- } \\
\text { controlled, } \\
\text { parallel-group, } \\
\text { fixed-dose } \\
\text { study; } 8 \text { weeks }\end{array}$ & $\begin{array}{l}518 \\
505 \\
\text { intent- } \\
\text { to-treat- } \\
\text { popula- } \\
\text { tion }\end{array}$ & $\begin{array}{l}\text { Adult male and } \\
\text { female patients } \\
\text { of age } 18-70 \text { years } \\
\text { inclusive, meeting } \\
\text { DSM-IV-TR criteria } \\
\text { with an ongoing } \\
\text { major depressive } \\
\text { episode lasting for at } \\
\text { least } 8 \text { weeks and up } \\
\text { to } 12 \text { months }\end{array}$ & $\begin{array}{l}\text { Vilazodone }(n=253) \\
\text { different doses: } \\
10 \mathrm{mg} / \text { day (week } 1) \\
20 \mathrm{mg} / \text { day (week 2), } \\
\text { and } 40 \mathrm{mg} / \text { day } \\
\text { (weeks 3-8), placebo } \\
(n=252)\end{array}$ & $\begin{array}{l}\text { Low incidence of } \\
\text { TESD was observed } \\
\text { Vilazodone treated } \\
\text { male patients } \\
\text { reported ED and } \\
\text { delayed ejaculation } \\
\text { more than placebo } \\
\text { group. Erectile } \\
\text { dysfunction: } n=6 \text {, } \\
\text { male sexual } \\
\text { dysfunction: } n=2 \text {, } \\
\text { ejaculation delay, } \\
n=3\end{array}$ \\
\hline $\begin{array}{l}\text { Jacobsen et al. } \\
\text { (2015) [34] }\end{array}$ & $\begin{array}{l}\text { Long-term, } \\
\text { phase III, open- } \\
\text { label, flexible- } \\
\text { dose extension } \\
\text { clinical study } \\
\text { in patients } \\
\text { who completed } \\
\text { one of three } \\
\text { randomized, } \\
\text { double-blind, } \\
\text { placebo- } \\
\text { controlled, } \\
\text { 8-week } \\
\text { vortioxetine } \\
\text { trials; } \\
52 \text { weeks }\end{array}$ & 1075 & $\begin{array}{l}\text { Adult male }(n=285) \\
\text { or female patients } \\
(n=790) \text { of age } \\
18-75 \text { years with } \\
\text { MDD according to } \\
\text { DSM-IV-TR criteria }\end{array}$ & $\begin{array}{c}\text { Vortioxetine } \\
(n=1073) \\
10 \mathrm{mg} / \text { day (week 1) } \\
\text { and then adjusted to } \\
15 \text { to } 20 \mathrm{mg} / \text { day }\end{array}$ & $\begin{array}{l}\text { Low incidence of } \\
\text { TESD, including ED } \\
\text { and ejaculation } \\
\text { disorder. } 5 \text { patients } \\
\text { had ED, } 2 \text { patients } \\
\text { had male SD, } 1 \text { had } \\
\text { ejaculation delay, } \\
1 \text { had ejaculation } \\
\text { disorder, and } 1 \text { had } \\
\text { ejaculation failure }\end{array}$ \\
\hline
\end{tabular}

Venlafaxine is a selective norepinephrine reuptake inhibitor (SNRI), trazodone is a serotonin receptor antagonist and reuptake inhibitor (SARI), duloxetine is a selective serotonin and norepinephrine reuptake inhibitor (SNRI), reboxetine is a selective noradrenaline reuptake inhibitor (NaRI).

Table III. Jaded Quality Score of the included randomized controlled trials

\begin{tabular}{|lllcc|}
\hline $\begin{array}{l}\text { Study (author and year } \\
\text { of study) }\end{array}$ & \multicolumn{4}{l}{ Factors and Jaded score } \\
\cline { 2 - 5 } & Randomization & Blinding & $\begin{array}{c}\text { Withdrawals } \\
\text { and dropouts }\end{array}$ & Total Jaded score \\
\hline Khazaie et al. (2015) [7] & 2 & 0 & 1 & 3 \\
\hline Clayton et al. (2015) [22] & 2 & 1 & 1 & 3 \\
\hline Croft et al. (2014) [30] & 2 & 2 & 1 & 5 \\
\hline Gelenberg et al. (2013) [31] & 1 & 1 & 1 & 3 \\
\hline Jacobsen et al. (2015) [34] & 1 & 1 & 1 & 3 \\
\hline Jacobsen et al. (2015) [33] & 2 & 2 & 1 & 5 \\
\hline Mathews et al. (2014) [29] & 2 & 2 & 0 & 3 \\
\hline Crawford et al. (2014) [28] & 2 & 0 & 1 & 0 \\
\hline Williams et al. (2010) [35] & 0 & 0 & 1 & 4 \\
\hline Boulenger et al. (2014) [32] & 2 & & 1 & 5 \\
\hline
\end{tabular}

Score 0-2 indicates low quality; Score 3-5 indicates high quality. 
CSFQ-14 total score indicates worsening of sexual functioning, which is defined as TESD [36]. SD in men was defined as a CSFQ score up to 47 and in women up to 41 [22]. The Arizona sexual experience scale (ASEX), a five-item rating scale, was used by Williams et al. to evaluate sexual functioning (sex drive, arousal, ability to reach orgasm, satisfaction with orgasm, and penile erection for males or vaginal lubrication for females) of the participants [35]. The study by Boulenger et al. also used the ASEX score to assess the number of participants who were normal at baseline but developed SD during the study period and SD was defined as an ASEX total score of at least 19, a score of minimum 5 on any item or a score of minimum 4 on any three items [32]. One study used the Hamilton Depression Rating Scale for sexual function assessment, where SD was defined as an item 14 (genital symptoms) score of 2 , where 0 indicates none, 1 mild, and 2 severe [31]. Croft et al., in their study, did not include a scale to measure sexual function [30].

\section{Treatment-emergent sexual dysfunction particularly erectile dysfunction in depressed men}

There were a total of 7543 male and female participants in ten included studies. The details of TESD among the participants of the included studies are described in Table II. Khazaie et al. noted a significant difference $(p<0.05)$ in SD in males across different antidepressant drugs used (fluoxetine, sertraline, and trazodone, a serotonin receptor agonist and reuptake inhibitor or SARI) with the highest SD in the fluoxetine group [7]. Erectile dysfunction and premature ejaculation were the two most common TESDs observed in males [7]. In the fluoxetine group, 51\%, $46 \%$, and $46 \%$ of males and in the sertraline group, $42 \%, 39 \%$, and $39 \%$ of males showed less vigorous erections, fewer sustained erections, and fewer spontaneous erections, respectively [7]. Fluoxetine was correlated with maximum impairment (43-51\%) and impairment in desire or drive-related items in SFQ was less in the sertraline than in the fluoxetine group [7]. Moreover, impairment in arousal/orgasm items was greater in males than in females [7]. Gelenberg et al. reported that out of 381 males (105 receiving fluoxetine and 276 receiving venlafaxine), three patients $(0.078 \%)$ receiving fluoxetine developed ED and the proportion of the fluoxetine-treated patients reporting new-onset SD including abnormal ejaculation, anorgasmia, and decreased libido peaked at week 6 [31].

In a long-term, phase III, open-label clinical study with vortioxetine, a low rate of TESD was observed among the participants; out of 285 males, only 5 (1.75\%) developed ED and 3 (1.05\%) had ejaculation-related problems [34]. In one study with 447 participants, out of whom 184 were males receiving escitalopram or vortioxetine, nine patients in the escitalopram group reported reduced libido, one reported disturbance in sexual arousal and ED (0.54\%), and one reported delayed and failed ejaculation; in contrast, the patients receiving vortioxetine did not report spontaneously treatment emergent adverse effects (TEAEs) related to SD [33]. In this study, the difference between the effect of vortioxetine and escitalopram was found to be significant only in men; mean (SD) increase in CSFQ-14 total score was significantly higher in the vortioxetine group (8.8) than in the escitalopram group (6.6; $p=0.013)$ [33]. In a study by Boulenger et al. including 207 males, TESD (orgasm abnormality, ejaculation delay and disorder, ED, reduced SD, orgasmic sensation, reduced libido) was found in $2.0 \%$ of patients taking vortioxetine $15 \mathrm{mg}$, in $4.0 \%$ of patients taking vortioxetine $20 \mathrm{mg}$, and in $2.5 \%$ of the placebo group, and in $3.5 \%(n=5)$ of patients taking duloxetine, indicating that there was not much difference between the effects of vortioxetine (15 mg and $20 \mathrm{mg}$ ) and placebo on SD in male MDD patients [32].

Crawford et al. noted that ED and difficulty in ejaculation appeared in males within 2 weeks of citalopram administration and the AE was gradually reduced over the 12-week study period [28]. Moreover, there was a large amount of missing data for the questions linked to male-specific AEs, especially for ED, $86 \%(n=160)$ at 2 weeks, $86 \%$ $(n=149)$ at 6 weeks, and $85 \%(n=124)$ at 12 weeks [28].

In a placebo-controlled study with vilazodone, more male patients receiving vilazodone treatment than treated with placebo showed ED ( $(n=$ 6), $4.8 \%$ vs. $0.9 \%)$ ) and delayed ejaculation $((n=$ 3), $2.4 \%$ vs. 0) [30]. In another placebo-controlled study with two doses of vilazodone $(20 \mathrm{mg} /$ day and $40 \mathrm{mg} /$ day), citalopram, and placebo involving a total 1138 male and female patients, three male patients (frequency: 2.4 to $2.6 \%$ ) developed $E D$ in each of the three intervention groups - placebo, vilazodone (40 mg/day), and citalopram - and the frequency of ejaculation delay among males was $0.8 \%$ in vilazodone (20 mg/day), $1.6 \%$ in vilazodone $(40 \mathrm{mg} /$ day $)$, and $1.7 \%$ in citalopram groups [29]. The overall TESD was found to be higher in males receiving citalopram compared to vilazodone and placebo [29]. Clayton et al., in their study with adult male and female MDD patients who were treated with vilazodone $(20 \mathrm{mg} /$ day), vilazodone (40 mg/day), citalopram, and placebo, found an increase in CSFQ total score in all treatment groups from baseline to week 10 , and in men the mean change of score was 3.5 for placebo, 2.4 for vilazodone (20 mg/day), 1.2 for vilazodone (40 mg/day), and 2.1 for citalopram 
[22]. Moreover, the occurrence of ED in males appeared with similar frequencies in the citalopram (2.6\%), vilazodone (2.4\%), and placebo (2.4\%) groups [22]. In a study involving three European countries (Germany, Spain, and the Netherlands) with MDD patients receiving different SSRI and SNRI antidepressants (including fluoxetine, sertraline, citalopram, paroxetine, and venlafaxine) the estimated prevalence of SD due to SSRIs or SNRI treatment was $37.1 \%$ in Germany, $61.5 \%$ in Spain, and $53.4 \%$ in the Netherlands [35]. Overall, $46.4 \%$ of male participants were classified as the anti-depressant-associated sexual dysfunction (AASD) group [35]. Percentages of males reporting about the worst ED were $22.6 \%$ in Germany, $9.6 \%$ in Spain, and $16.4 \%$ in the Netherlands [35].

\section{Discussion}

This systematic review included data from ten studies with more than 7500 male and female MDD patients receiving various SSRIs. The methodological quality assessment of nine studies yielded a good score and only one study had poor quality since it was a cross-sectional survey and thus could not be assessed by the Jaded scoring system [35]. However, we had to include that study due to the lack of adequate studies. Despite limited availability and heterogeneity of studies, there is some evidence that SD in males, which can involve any or all phases of the sexual cycle (such as arousal, libido, orgasm, and ejaculation), is associated with the use of SSRI antidepressants used to treat MDD. Among different TESDs, ED was reported in a small percentage of depressed males ( $<$ than even $2 \%$ ) treated with SSRIs. This can be attributed to underreporting; ED being an intimate subject bears a risk of bias and the men had a tendency to underreport this issue [37]. The study by Gelenberg et al. detected that the rates of TESD assessed based on direct queries about sexual functioning were higher than the spontaneously reported TESDs [31]. Missing data for male SD, particularly related to ejaculation and penile erection, were observed in the study by Crawford et al. [28]. Moreover, there was variation in the tools used to measure sexual function in the studies, which may result in a difference in outcome measures of the different studies.

SSRIs prevent the reuptake of $5 \mathrm{HT}$ through an antagonistic effect on the serotonin transporter, thus elevating the level of $5 \mathrm{HT}$ in synapses, which in turn causes SD [13]. The etiology of ED is multifactorial, involving endothelial dysfunction, microvascular disease, change in testosterone levels, neurological, and psychological factors [37, 38]. Besides age, comorbidities, and psychiatric symptoms, specific antidepressants might contribute to ED pathogenesis [38]. Erectile dysfunction emerging from SSRI medication is thought to result from the direct penile effect of serotonin [17]. The effects of SSRIs on spontaneous and sexually aroused erections might be under the control of both central and peripheral nervous systems [24]. A study by Corona et al. detected that individuals using SSRI medications had a lower sexual desire and increased ED [17]. Reduced nocturnal or even morning erections could be partly due to SSRI-induced suppression of rapid eye movement $[17,24]$. Decreased NO production affects penile erection. Different classes of antidepressants may induce SD in different mechanisms and to a different extent [7].

Paroxetine, an SSRI drug, inhibits the action of NO synthase, thereby lowering the level of NO. Although the mechanism of interaction is not known properly, it is assumed that three NO synthase isozymes bear structural similarity with cytochrome P450 (CYP450) [24]. Paroxetine, being a potent inhibitor of CYP2D6, lowers the levels of $\mathrm{NO}$ in patients taking this drug and may lead to the development of ED among them [24]. However, in the current review only one included study used paroxetine and the findings were inconclusive [35]. Vilazodone (20 and $40 \mathrm{mg} /$ day), a novel antidepressant, which is an SSRI as well as 5-HT1A receptor partial agonist, was found to cause ED in similar frequency as that of placebo and citalopram-treated male patients [22, 29]. Also, the incidence of the TESD was found to be less than $5 \%$ in both vilazodone and placebo-treated groups in an 8-week, double-blind, placebo-controlled study by Croft et al. [30]. Nonetheless, more male patients treated with vilazodone vs placebo reported ED and delayed ejaculation [30]. Moreover, vilazodone was found to be better tolerated among the participants of this study [30].

Vortioxetine was also found to be an effective, safe, and tolerable drug for long-term treatment of MDD patients at higher doses $(15 \mathrm{mg} /$ day or $20 \mathrm{mg} /$ day) since they cause mild to moderate TEAEs, particularly SD [34]. The most remarkable $A E$ associated with vortioxetine was nausea, with an incidence of $\geq 5 \%[32,33]$. Vortioxetine was found to be well tolerated, with a low rate of patient discontinuation due to TEASs [32, 33]. In the placebo-controlled study, vortioxetine showed male SD in a similar frequency as that of placebo [32]. In the study comparing the effect of vortioxetine and escitalopram on sexual functioning in adults with MDD, patients receiving escitalopram spontaneously reported about TESD, such as ED, anorgasmia, disturbance in sexual arousal, and failed ejaculation, whereas patients on vortioxetine did not spontaneously report any TESD [33].

Another SSRI fluoxetine showed a higher level of sexual impairment in all SFQ items in a study by 
Khazaie et al., particularly less vigorous erections, fewer sustained erections, and fewer spontaneous erections compared to sertraline [7]. Sertraline works by blocking the reuptake of dopamine in a higher dose and increases the availability of dopamine; unlike serotonin, dopamine increases sexual function and therefore produces fewer sexual AEs [7]. Moreover, about $40 \%$ to $50 \%$ of patients with normal baseline sexual function experienced TESD during 6-month treatment with fluoxetine [31]. Among all the SSRIs used in the included studies, fluoxetine, escitalopram, and citalopram showed a stronger association with SD and/or ED compared to vilazodone, vortioxetine, and sertraline.

In this review, treatment-emergent SD at different stages of sexual cycles was observed among the male and female MDD patients taking antidepressant medications. In males, ED and ejaculation problems were observed as the two common AEs in the majority of the included studies [7, 22, 28-34]. In MDD patients, SD is commonly associated with both the condition and the treatment (use of SSRI and SNRI antidepressants) [22]. The antidepressants have a positive impact (causing symptom improvement) and negative serotonergic effects (causing SD and other AEs) [22]. Improvement in sexual functioning during an effective antidepressant treatment indicates a balance between the positive and negative effects of SSRI medications so that a patient can have mood and sexual function enhancement [22]. Emphasis has been placed on the importance of individual assessment of probable benefits and harms when selecting antidepressants, since a simple adjustment of different SSRIs (fluoxetine, citalopram, or escitalopram) is not sufficient to obtain better patient outcomes [39]. Hence, clinical management of MDD can be improved by assessing the patient factors (e.g. sex, baseline sexual activity) and treatment factors (mechanism of action of the antidepressants and response to antidepressant medications) [22].

The main strength of this review was its systematic nature in assembling the published literature of the last ten years on the development of treatment-emergent SD in males, particularly ED because of the use of SSRI antidepressants utilizing rigorous methodology with a wide search strategy. A further strength is that the review involved a wide variety of SSRIs, which allowed assessment of the effects of different SSRIs on sexual functioning.

This study has several limitations. Firstly, this review only included the studies published in the English language and excluded non-peer-reviewed articles and grey literature; in fact there was a scarcity of relevant articles to be included in this review due to which studies containing both males and females were included. However, only ED, characteristic of men, was focused on. Secondly, the observed differences in medication dosages, study duration, or any confounding from simultaneous use of medications or comorbid conditions impacting sexual function, were not considered. Thirdly, the majority of the RCTs included were of shorter duration of 5-12 weeks, except one long-term study of 52 weeks [34], which did not allow evaluation of the long-term effects of different SSRIs on the development of TESD. Fourthly, some of the RCTs did not report baseline SD (which is crucial to know the effect of the drugs); therefore overestimation of the reported rates of SD can occur in these trials. The fifth limitation was that the severity of ED was not described, because of the unavailability of data in the included studies. Finally, the results were narrative, rather than a meta-analysis, which was not possible because of the lack of consistency and variable quality of data among the heterogeneous studies. The heterogeneity of the studies makes it difficult to draw firm inferences from this review. Despite these limitations, the review is a helpful collection of studies depicting the $A E$ of SSRI antidepressants on the sexual functioning of adult males suffering from MDD. The tentative conclusions may be beneficial for directing future research.

In conclusion, the present systematic review highlighted a positive association between SSRI antidepressants and SD. The comparative risk of SD associated with a specific antidepressant was also detected. However, the correlation between different SSRIS and ED development in men cannot be precisely determined due to limited evidence. The onset of treatment-emergent ED or any form of SD (e.g. delayed ejaculation, reduced libido) is a major disadvantage of SSRI medication, which might be distressful for the MDD patient, and they may start to discontinue the medication [10]. This affects the treatment procedure [16]. In this review, we observed that the SSRIS fluoxetine, escitalopram, and citalopram showed a higher risk of SD and/or ED than other SSRIs. Treating both depression and anxiety symptoms along with avoiding SD is found to be important for physicians prescribing antidepressants. Therefore, clinicians should consider SSRI as a risk factor of SD/ED and must regularly discuss with the patients about the adverse sexual effects of different SSRIs. Furthermore, the clinicians must consider the patients' preferences when selecting an SSRI antidepressant, which is less likely to be associated with SD, and monitor the treatment at the same time. Additional scientific investigations are essential to explore the underlying mechanism of interaction between different SSRIs and ED development. 


\section{Acknowledgments}

The author is thankful to Turacoz Healthcare Solutions (www.turacoz.com) for selecting articles and proofreading the manuscript.

\section{Conflict of interest}

The authors declare no conflict of interest.

\section{References}

1. Bromet E, Andrade L, Hwang I, et al. Cross-national epidemiology of DSM-IV major depressive episode. BMC Med 2011; 9: 90.

2. Reichenpfader U, Gartlehner G, Morgan LC, et al. Sexual dysfunction associated with second-generation antidepressants in patients with major depressive disorder: results from a systematic review with network meta-analysis. Drug Saf 2014; 37: 19-31.

3. The World Health Report 2001: Mental Health: New understanding, New hope. France, Organization WH.

4. Lim GY, Tam W, Lu Y, Ho CS, Zhang MW, Ho RC. Prevalence of depression in the community from 30 countries between 1994 and 2014. Sci Rep 2018; 8: 2861.

5. Armstrong C. APA releases guidelines on treatment of patients with major depressive disorder. Am Fam Physician 2011; 83: 1219-27.

6. Gauthier G, Guerin A, Zhdanava M, et al. Treatment patterns, healthcare resource utilization, and costs following first-line antidepressant treatment in major depressive disorder: a retrospective US claims database analysis. BMC Psychiatry 2017; 17: 222.

7. Khazaie H, Rezaie L, Payam NR, Najafi F. Antidepres sant-induced sexual dysfunction during treatment with fluoxetine, sertraline and trazodone: a randomized controlled trial. Gen Hosp Psychiatry 2015; 37: 40-5.

8. Qaseem A, Snow V, Denberg TD, Forciea MA, Owens DK, Clinical Efficacy Assessment Subcommittee of American College of P. Using second-generation antidepressants to treat depressive disorders: a clinical practice guideline from the American College of Physicians. Ann Intern Med 2008; 149: 725-33.

9. Saltiel PF, Silvershein DI. Major depressive disorder: mechanism-based prescribing for personalized medicine. Neuropsychiatr Dis Treat 2015; 11: 875-88.

10. Jing E, Straw-Wilson K. Sexual dysfunction in selective serotonin reuptake inhibitors (SSRIs) and potential solutions: a narrative literature review. Ment Health Clin 2016; 6: 191-6.

11. Arroll B, Macgillivray S, Ogston S, et al. Efficacy and tolerability of tricyclic antidepressants and SSRIs compared with placebo for treatment of depression in primary care: a meta-analysis. Ann Fam Med 2005; 3: 449-56.

12. Gartlehner G, Hansen RA, Morgan LC, et al. Comparative benefits and harms of second-generation antidepressants for treating major depressive disorder: an updated meta-analysis. Ann Intern Med 2011; 155: 772-85.

13. Osis L, Bishop JR. Pharmacogenetics of SSRIs and sexual dysfunction. Pharmaceuticals 2010; 3: 3614-28.

14. Williams JW Jr, Mulrow CD, Chiquette E, Noel PH, Aguilar C, Cornell J. A systematic review of newer pharmacotherapies for depression in adults: evidence report summary. Ann Intern Med 2000; 132: 743-56.

15. Higgins A, Nash M, Lynch AM. Antidepressant-associated sexual dysfunction: impact, effects, and treatment. Drug Healthc Patient Saf 2010; 2: 141-50.
16. Thapa M, Petrakis I, Ralevski E. A comparison of antidepressants with/without naltrexone on sexual side effects. J Dual Diagn 2017; 13: 230-5.

17. Corona G, Ricca V, Bandini E, et al. Selective serotonin reuptake inhibitor-induced sexual dysfunction. J Sex Med 2009; 6: 1259-69.

18. Clayton AH, Croft HA, Handiwala L. Antidepressants and sexual dysfunction: mechanisms and clinical implications. Postgrad Med 2014; 126: 91-9.

19. La Torre A, Duffy D, Conca A. Sexual dysfunction related to psychotropic drugs: a critical review - part I: antidepressants. Pharmacopsychiatry 2013; 46: 191-9.

20. Keltner NL, McAfee KM, Taylor CL. Mechanisms and treatments of SSRI-induced sexual dysfunction. Perspect Psychiatr Care 2002; 38: 111-6.

21. Reisman Y. Sexual Consequences of post-SSRI syndrome. Sex Med Rev 2017; 5: 429-33.

22. Clayton AH, Gommoll C, Chen D, Nunez D, Mathews M Sexual dysfunction during treatment of major depressive disorder with vilazodone, citalopram, or placebo: results from a phase IV clinical trial. Int Clin Psychopharmacol 2015; 30: 216-23.

23. Simopoulos E, Trinidad AC. Male erectile dysfunction: integrating psychopharmacology and psychotherapy. Gen Hosp Psychiatry 2013; 35: 33-8.

24. Prabhakar D, Balon R. How do SSRIs cause sexual dysfunction? Curr Psychiatry 2010; 9: 30-4.

25. Montejo-Gonzàlez AL, Llorca G, Izquierdo JA, et al. SSRIi-Induced sexual dysfunction: fluoxetine, paroxetine, sertraline, and fluvoxamine in a prospective, multicenter, and descriptive clinical study of 344 patients. J Sex Marital Ther 1997; 23: 176-97.

26. Moher D, Liberati A, Tetzlaff J, Altman DG; the PRISMA Group. Preferred reporting items for systematic reviews and meta-analyses: the PRISMA statement. Ann Intern Med 2009; 151: 264-9.

27. Rahimi R, Nikfar S, Abdollahi M. Selective serotonin reuptake inhibitors for the managementof irritable bowe syndrome: a meta-analysis of randomized controlled trials. Arch Med Sci 2008; 4: 71-6.

28. Crawford AA, Lewis S, Nutt D, et al. Adverse effects from antidepresssant treatment: randomised controlled trial of 601 depressed individuals. Psychopharmacology 2014; 231: 2921-31.

29. Mathews M, Gommoll C, Chen D, et al. Efficacy and safety of vilazodone 20 and $40 \mathrm{mg}$ in major depressive disorder: a ranadomized, double-blind, placebo-controlled trial. Int Clin Psychopharmacol 2015; 30: 67-74.

30. Croft HA, Pomara N, Gommoll C, et al. Efficacy and safety of vilazodone in major depressive disorder: a randomized, double-blind, placebo-controlled trial. J Clin Psychiatry 2014; 75: e1291-8.

31. Gelenberg AJ, Dunner DL, Rothschild AJ, et al. Sexual functioning in patients with recurrent major depressive disorder enrolled in the PREVENT study. J Nerv Ment Dis 2013; 201: 8.

32. Boulenger JP, Loft $H$, Olsen CK. Efficacy and safety of vortioxetine (Lu AA21004), 15 and 20 mg/day: a randomized, double-blind, placebo-controlled, duloxetine-refernced study in the acute treatment of adult patients with major depressive disorder. Int Clin Psychopharmacol 2014; 29: 138-49.

33. Jacobsen PL, Mahableshwarkar A, Chen Y, et al. Effect of vortixetine vs. escitalopram on sexual functioning in adults with well-treated major depressive disorder experiencing SSRI-induced sexual dysfunction. J Sex Med 2015; 12: 2036-48. 
34. Jacobsen PL, Harper L, Chrones L, et al. Safety and tolerability of vortioxetine (15 and $20 \mathrm{mg}$ ) in patients with major depressive disorder: results of an open-label, flexible-dose, 52-week extension study. Int Clin Psychopharmacol 2015; 30: 255-64.

35. Williams VSL, Edin H, Hogue SL, Fehnel SE, Baldwin DS. Prevalence and impact of antidepressant-associated sexual dysfunction in three European countries: replication in a cross-sectional patient survey. J Psychopharmacol 2010; 24: 489-96.

36. Jacobsen PL, Zhong W, Nomikos G, Clayton AH. Paroxetine, but not vortioxetine, impairs sexual functioning compared with placebo in healthy adults: a randomized, controlled trial. J Sex Med 2019; 16: 1638-49.

37. Weber P, Schmidutz F, Ficklscherer A, Steinbrück A, Jansson V, Dürr HR. Does total joint arthroplasty impair erectile function? Arch Med Sci 2018; 14: 1087-92.

38. Du XL, Liu L, Song W, et al. Association between gout and erctile dysfunction: a systematic review and metaanalysis. PLoS One 2016; 11: e0168784.

39. Aronow WS, Shamliyan TA. Effects of antidepressants on QT interval in people with mental disorders. Arch Med Sci 2020; 16: 727-41. 